\begin{tabular}{|c|l|}
\hline Title & Molecular cloning and characterization of the corticoid receptors from the A merican all ligator \\
\hline Author(s) & $\begin{array}{l}\text { Oka, Kaori; Kohno, Satomi; Urushitani, Hiroshi; Guillette, Louis J., Jr.; Ohta, Y asuhiko; Iguchi, Taisen; Katsu, } \\
\text { Yoshinao }\end{array}$ \\
\hline Citation & $\begin{array}{l}\text { Molecular and Cellular Endocrinology, 365(2), 153-161 } \\
\text { https://doi.org/10.1016/.mce.2012.10.014 }\end{array}$ \\
\hline Issue Date & 2013-01-30 \\
\hline Doc URL & http://hdl.handle.net/2115/52257 \\
\hline Type & article (author version) \\
\hline Additional Information & There are other files related to this item in HUSCAP. Check the above URL. \\
\hline File Information & MCE365-2_153-161.pdf \\
\hline
\end{tabular}

Instructions for use 


\section{Molecular cloning and characterization of the corticoid receptors from the American alligator}

Short title: alligator glucocorticoid and mineralocorticoid receptors

Kaori Oka ${ }^{1}$, Satomi Kohno ${ }^{2}$, Hiroshi Urushitani ${ }^{\mathbf{3}}{ }^{4}$, a , Louis J. Guillette $\mathrm{Jr}^{2}{ }^{2}$, Yasuhiko Ohta ${ }^{\mathbf{5}}$, Taisen Iguchi $^{\text {3, 4, \# } \text { and Yoshinao Katsu }}{ }^{1,3,6, \#}$

${ }^{1}$ Graduate School of Life Science, Hokkaido University, Sapporo 060-0810, Japan;

${ }^{2}$ Department of Obstetrics and Gynecology, Medical University of South Carolina and Hollings Marine Laboratory, 221 Ft. Johnson Rd., Charleston, SC 29412, USA; ${ }^{3}$ Okazaki

Institute for Integrative Bioscience, National Institutes of Natural Sciences, Okazaki

444-8787, Japan ; ${ }^{4}$ National Institute for Basic Biology, Okazaki 444-8787, Japan ;

${ }^{5}$ Department of Veterinary Medicine, Faculty of Agriculture, Tottori University, Tottori

680-8553, Japan; $\quad{ }^{6}$ Department of Biological Sciences, Hokkaido University, Sapporo 060-0810, Japan

\#Address all correspondence to: Taisen Iguchi or Yoshinao Katsu, Okazaki Institute for Integrative Bioscience, National Institutes of Natural Sciences, Okazaki 444-8787, Japan (T.I.), or Department of Biological Sciences, Hokkaido University, Kita-10, Nishi-8, Kita-ku, Sapporo 060-0810, Japan (Y.K.).

E-mail:taisen@nibb.ac.jp (Taisen Iguchi); or ykatsu@sci.hokudai.ac.jp (Yoshinao Katsu)

${ }^{\text {a}}$ Present address: Environmental Quality Measurement Section, Research Center for Environmental Risk, National Institute for Environmental Studies, 16-2 Onogawa, Tsukuba, Ibaraki 305-8506, Japan

Disclosure statement: All authors have nothing to disclose.

Key words: alligator, glucocorticoid receptor, mineralocorticoid receptor, cloning, transactivation

Abbreviations: GR, glucocorticoid receptor; MR, mineralocorticoid receptor; RACE, rapid amplification cDNA ends; MMTV, murine mammary tumor virus; DMSO, dimethylsulfoxide 


\begin{abstract}
Steroid hormones are essential for health in vertebrates. Corticosteroids, for example, have a regulatory role in many physiological functions, such as osmoregulation, respiration, immune responses, stress responses, reproduction, growth, and metabolism. Although extensively studied in mammals and some non-mammalian species, the molecular mechanisms of corticosteroid hormone (glucocorticoids and mineralocorticoids) action are poorly understood in reptiles. Here, we have evaluated hormone receptor-ligand interactions in the American alligator (Alligator mississippiensis), following the isolation of cDNAs encoding a glucocorticoid receptor (GR) and a mineralocorticoid receptor (MR). The full-length alligator GR (aGR) and aMR cDNAs were obtained using 5' and 3' rapid amplification cDNA ends (RACE). The deduced amino acid sequences exhibited high identity to the chicken orthologs (aGR: 83\%; aMR: 90\%). Using transient transfection assays of mammalian cells, both aGR and aMR proteins displayed corticosteroid-dependent activation of transcription from keto-steroid hormone responsive, murine mammary tumor virus promoters. We further compared the ligand-specifity of human, chicken, Xenopus, and zebrafish GR and MR. We found that the alligator and chicken GR/MR have very similar amino acid sequences, and this translates to very similar ligand specificity. This is the first report of the full-coding regions of a reptilian GR and MR, and the examination of their transactivation by steroid hormones.
\end{abstract}




\section{Introduction}

Steroid hormones are essential for health in all vertebrates, including reptiles, with many reported actions. These actions are mediated, at least in part, by specific receptors localized in or near the nucleus of target cells. Two distinct types of corticosteroid receptor, a glucocorticoid receptor (GR) and a mineralocorticoid receptor (MR) have been isolated in vertebrates to date. Corticosteroid hormones, the glucocorticoids and mineralocorticoids, were originally named for their distinct physiological functions in mammals. Glucocorticoids, including cortisol and corticosterone, were identified for their role in liver glycogen deposition, whereas the mineralocorticoid, predominantly aldosterone, regulated mineral balance principally by controlling sodium retention in the kidney (Norman and Litwack, 1997).

Thornton (2001) proposed that the ancestral condition for the jawed vertebrates (Gnathostomata) was the presence of two forms of corticosteroid receptor. Both forms have been found in chondrichthyan and osteichthyan fishes, amphibians, birds and mammals. To data, however, cDNAs encoding full length GR and MR have not been reported for a reptile nor has their function been compared with other vertebrate classes. These receptors are important as they hold a basal position in the evolution of vertebrate steroid receptors (Thornton, 2001) and the reptilian forms would add to our understanding of the evolution and function of these receptors in phylogenetically related avian and mammalian species. A full-coding region of a reptilian (green anole, Anolis carolonensis) GR-like sequence has been registered in GenBank. However, as this sequence is predicted from genomic information (A. carolinesis chromosome 2 genomic scaffold, AnCar2.0, whole genome shotgun sequence, NW_003338615), the functional analysis of this receptor was not reported.

Here, we report the isolation of cDNA clones encoding American alligator (Alligator mississippiensis) homologs of the glucocorticoid and mineralocorticoid receptors. We analyzed their phylogenic relationship with other known vertebrate steroid receptors. The transactivation functions of GR and MR were determined by expressing these two receptors separately in transiently transfected cultured cell lines, using a general reporter gene assay. Further, we compared the ligand-specificity of GR and MR from the alligator to other vertebrates (human, chicken, Xenopus, and zebrafish) .

\section{Materials and Methods}

\subsection{Animals}

All experiments in this study involving alligator were carried out under the guidelines specified by the Institutional Animal Care and use Committee at the University of Florida and National Institutes of Natural Sciences. All fieldwork was conducted under permits from 
the Florida Fish and Wildlife Conservation Commission and the U.S. Fish and Wildlife Service. Juvenile American alligators (A. mississippiensis) were collected by hand from airboats from the Lake Woodruff National Wildlife Refuge (NWR), Volusia County, Florida, USA. Animals were killed with a lethal dose of Nembutal, and tissues were isolated and stored at $-80^{\circ} \mathrm{C}$ until analysis.

Alligator eggs were collected from Lake Woodruff NWR, and transported to the University of Florida (Gainesville, FL, USA), where they were incubated in damp sphagnum moss at male-producing $\left(33.5^{\circ} \mathrm{C}\right)$ or female-producing $\left(30.0^{\circ} \mathrm{C}\right)$ temperatures. Embryonic developmental stages were determined primarily according to the criteria described by Ferguson (1985), with some further resolution based on our previous experience working with this species (Kohno and Guillette, 2012). Embryos were dissected at stages 19, 20, 21, 23 and 24. The gonad-adrenal-mesonephric complex (GAM) was isolated under sterile conditions and stored at $-80^{\circ} \mathrm{C}$ until analyzed. Neonates ( $<48$ hours old) and one-month-old animals were killed with a lethal dose of Nembutal, and GAM tissues were isolated and stored at $-80^{\circ} \mathrm{C}$ in RNAlater (Ambion, Austin, TX) until analyzed. GAMs isolated from one-month-old animal, and fixed in RNAlater, were carefully dissected into three portions; the gonad, adrenal and mesonephros (Kohno et al., 2010).

An adult female frog (Xenopus laevis) and zebrafish (Danio rerio) were purchased from a local supplier. Animals were overdosed with MS-222 and tissues obtained by sterile necropsy.

\subsection{Chemical reagents}

We obtained chemicals from Sigma-Aldrich Corp.; aldosterone, deoxycorticosterone, corticosterone, cortisol, cortisone, pregnenolone, progesterone,

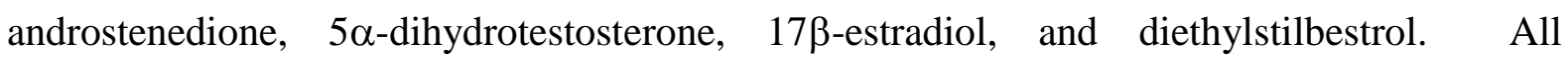
chemicals were dissolved in dimethylsulfoxide (DMSO). The concentration of DMSO in the culture medium did not exceed $0.1 \%$.

\subsection{Molecular cloning of steroid hormone receptors}

For the MR, two conserved amino acid regions (FMDDKDY and QVVKWAK) of vertebrate MRs were selected and degenerate oligonucleotides were used as primers for polymerase chain reaction (PCR). As a template for PCR, the first-strand cDNA was synthesized from $2 \mu \mathrm{g}$ of total RNA isolated from the alligator liver. After amplification, an additional primer set, QSFHYRI and IVYAGYD, was used for the second PCR. For the GR, two conserved amino acid regions, QVKTEKE/D and QNWQRFY of vertebrate GRs were selected and degenerate oligonucleotides were used as primers for PCR. First-strand cDNA 
was synthesized from $2 \mu \mathrm{g}$ of total RNA isolated from the liver of alligator after amplification, and an additional primer set, GQMYHYD and NMLGGRQ, was used for the second PCR.

The amplified DNA fragments were subcloned with the TA-cloning plasmid pCR2.1 vector (Invitrogen, Carlsbad, CA), sequenced using a BigDye terminator Cycle Sequencing-kit (Applied Biosystems, Foster City, CA) with T7 and SP6 primers, and analyzed on an Applied Biosystems 3130 Genetic Analyzer (Applied Biosystems). The 5'and 3'-ends of the MR and GR cDNAs were amplified by rapid amplification of the cDNA end (RACE) using a SMART RACE cDNA Amplification kit (BD Biosciences Clontech, Palo Alto, CA). All sequences generated were searched for similarity using Blastn and Blastp on the web servers of the National Center of Biotechnology Information.

\subsection{Construction of plasmid vectors}

The full-coding regions of the alligator GR, human GR (accession number; NM_000901), chicken GR (accession number; NM_001159345), Xenopus GR (accession number; NM_001090605), zebrafish GR (accession number; NM_001100403), alligator MR, human MR (accession number; NM_000176,), chicken MR (accession number; NM_001037826), Xenopus MR (accession number; NM_001088062), and zebrafish MR (accession number; NM_001100403) were amplified by PCR with KOD DNA polymerase (TOYOBO Biochemicals, Osaka, Japan). The PCR products were gel-purified and ligated into the pcDNA3.1 vector (Invitrogen). The mouse mammary tumor virus-long terminal repeat (MMTV-LTR) was amplified from the pMSG vector (Pharmacia) by PCR, and inserted into the pGL3-basic vector that contained the Photinus pyralis lucifease gene (Promega).

\subsection{RNA isolation and RT-PCR}

Total RNA was prepared from tissues of both female and male alligators using RNeasy. For RT-PCR, $2 \mu \mathrm{g}$ of total RNA was reverse-transcribed using SuperScript III transcriptase (Invitrogen) and oligo (dT) primer. The following primer sets were used for RT-PCR: 5'-CACGCCATCCTGCGTCTGGACTTG-3' and 5'-ATTCTGTCGGCGATGCCAGGGTAC-3' for $\beta$-actin, 5'-CGTTCTGGTAAGAAGCTGGA-3' and 5'-TGACACCAACAGCAACAGTC-3' for $\mathrm{EF} 1 \alpha$, 5'-ATAGTTCCTGCATCACTGCCACAG-3' and 5'-TCAGGCCCTCCTTAGGAATTGTAG-3' for GR, 5'-AACCAGACACAGCAGAGTACCTGC-3' and 5'-TTCCACCAGCATGGCTGGAAACTC-3' for MR. Twenty-eight cycles (for $\beta$-actin and $\mathrm{EF} 1 \alpha$ ) or thirty cycles (for GR and MR) of amplification were carried out under the 
following conditions: denaturing at $94^{\circ} \mathrm{C}$ for $30 \mathrm{sec}$, annealing at $58^{\circ} \mathrm{C}$ for $30 \mathrm{sec}$, and extension at $72^{\circ} \mathrm{C}$ for $1 \mathrm{~min}$. At completion of the PCR, DNA fragments were resolved on $1.2 \%$ agarose gels.

\subsection{Transactivation assays}

Transcription assays were performed in human embryonic kidney 293 (HEK293) cell. HEK293 cells were seeded in 24 -well plates at $5 \times 10^{4}$ cells/well in phenol-red free Dulbecco's modified Eagle's medium (Sigma-Aldrich Corp.) with 10\% charcoal/dextran-treated fetal bovine serum (Hyclone, South Logan, UT). After $24 \mathrm{~h}$, the cells were transfected with DNAs using Fugene 6 transfection reagent (Roche Diagnostics, Basel, Switzerland) according to the manufacturer's instructions. After $20 \mathrm{~h}$ of incubation, steroid hormones were introduced to the media. After an additional $24 \mathrm{~h}$, the cells were collected, and the luciferase activity of the cells was measured by a chemiluminescence assay employing the Dual-Luciferase Reporter Assay System (Promega). Luminescence was measured using a Turner Designs Luminometer TD-20/20 (Promega). Promoter activity was calculated as firefly (Photinus pyralis)-luciferase activity/sea pansy (Renilla reniformis)-luciferase activity. All transfections were preformed in triplicate.

\subsection{Phylogenetic analysis and databases}

All sequences generated were searched for similarity using PSI-Blast with American alligator GR or MR at web servers of the National Center of Biotechnology Information. The searches were repeated until any new sequence would not be obtained within 500 sequences in the Protein Reference Sequences database. After brief analysis of the phylogeny with selected species, the data revealed AR and PR were the closest out-group of GR and MR as described before in Bridgham et al. (2009). Thus GR and MR were analyzed with AR and PR. Phylogenic tree was estimated by phylogeny.fr (Dereeper et al., 2008) with T-Coffee, Gblocks and phyML. MEGA5 were used to edit the phylogenic tree (Tamura et al., 2011). The NCBI gene ID of sequences in the phylogeny are: 324021675 , 324021673, 324021671, 321117150, 66528642, 58535455, 21322252, 4504133, 158508572, 112363098, 121247453, 144227212, 327269138, 327265250, 327285073, 226817306, 45383982, 301612214, 301607929, 62858859, 154240734 and 261599016.

\subsection{Statistical methods}

Results are presented as mean \pm SEM. Comparisons between two groups were performed using Student's $t$-test, and all multi-group comparisons were performed by ANOVA followed by Bonferroni post hoc analyses using GraphPad Prism (version 4.0c; 
GraphPad Software, Inc., San Diego, CA). $\quad P<0.05$ was considered statistically significant.

\section{Results}

\subsection{Alligator GR and MR}

Using standard PCR techniques, partial DNA fragments were amplified from alligator liver RNA. Two different DNA fragments were obtained showing similarity to the GR and MR, respectively. A full-length alligator GR cDNA (GenBank Accession No. AB701407) and MR cDNA (GenBank Accession No. AB701406) were cloned using RACE. The cDNA for alligator GR (aGR) is composed of a predicted 780 amino acids with a calculated molecular mass of $85.2 \mathrm{kDa}$, whereas the MR (aMR) is composed of a predicted 985 amino acids with a calculated molecular mass of $107.4 \mathrm{kDa}$ (Fig. 1). Using the nomenclature of Krust et al. (1986), the aGR and aMR sequences can be divided into four domains (A/B, C, D and $\mathrm{E}(\mathrm{F})$ domains) based on its sequence homology with other steroid hormone receptors. aGR and aMR shared 27\% identity in the A/B domain, 93\% identity in the $\mathrm{C}$ domain, $31 \%$ identity in the $\mathrm{D}$ domain, and $59 \%$ identity in the $\mathrm{E}(\mathrm{F})$ domain (Fig. 2A). Thus, the $\mathrm{C}$ domain (DNA-binding domain) is highly conserved, with the $\mathrm{E}(\mathrm{F})$ domain (ligand-binding domain) exhibiting conservation as well between the aGR and aMR. Amino acid sequences of the aGR and aMR with the other vertebrates examined, show an over-all homology of 39\%. The over-all homologies of aGR with human, chicken, Xenopus and alpha form zebrafish (Schaaf et al., 2008) GRs were 76, 83, 67 and 52\%, respectively. The over-all homologies of the aMR with human, chicken, Xenopus or zebrafish MRs were 82, 90, 68 and 54\%, respectively. When examined in greater detail, the aGR shared 76-34\%, $100-97 \%, 70-41 \%$, and $97-73 \%$ identities in the $\mathrm{A} / \mathrm{B}, \mathrm{C}, \mathrm{D}$, and $\mathrm{E}(\mathrm{F})$ domains with the other species examined, respectively (Fig. 2B). A similar analyses for the aMR indicated $87-44 \%$, $100-97 \%, 86-40 \%$, and $98-74 \%$ identities in the $\mathrm{A} / \mathrm{B}, \mathrm{C}, \mathrm{D}$, and $\mathrm{E}(\mathrm{F})$ domains, respectively (Fig. 2C). As would be predicted from previous studies using various forms of genetic information, a phylogenetic analysis indicated that the alligator corticoid receptors were more closely related to those of birds rather than those of mammals and amphibians (Fig. 3).

The mRNA expression levels of both corticoid receptors in various tissues, from both female and male juvenile alligators, were measured by RT-PCR. Expression of aGR in the female kidney, and female and male thyroid appeared less, based on the band intensity on the gel, compared with other tissues. Similarly, expression of the aMR in female and male thyroid, and the male gonad was lower compared with other tissues. We also analyzed the expression level of these receptors in the GAM during embryonic development. Both aGR and aMR mRNAs were detected at stages 19 and 24, stages just prior to and the last stage of the thermo-sensitive period for sex determination, but using gel band intensity alone, the 
expression of these receptors appears to show little or no difference (Fig. 4).

In the mouse mammary tumor virus (MMTV) promoter-based assay, the hormone-activated GR binds to a cluster of glucocorticoid response elements (GREs), and triggers nucleosomal rearrangement, probably by recruitment of co-activators (Majors and Varmus, 1983; Belikov et al., 2000). The MR also interacts with GREs and shows hormone-dependent transactivation via this response element (Govindan et al., 1991). The MMTV-LTR (long terminal repeat) contains glucocorticoid response elements (GREs), known to interact with MR (Couette et al., 1994). The MMTV promoter has been used extensively as a model to explore the processes by which the GR and MR remodels chromatin and activates transcription (Deroo and Archer, 2001). Based on these observations, we constructed an MMTV-driven reporter gene assay to examine the hormone-inducible transcriptional activation of aGR and aMR. Corticosteroids and progesterone (P4) were effective in inducing luciferase activity by the aGR. The aMR was stimulated by aldosterone, and deoxycorticosterone as well as corticosterone, and cortisol. No induction of the aMR was found following exposure to cortisone, but P4 weakly induced transactivation of the aMR. Neither androgens nor estrogens activated the aGR or aMR (Fig. 5). We found that cortisol $\left(10^{-6} \mathrm{M}\right)$ could activate the transcription of luciferase via MMTV promoter in HEK293 cell without transfected GR, but its activities were less than 2-fold increase compared with no-hormone (data not shown). HEK293 expresses GR (Kay et al., 2011), but we consider that inherent GR has a little effect in our assay system. We also applied a reporter gene assay using MMTV-driven reporter construct on the human hepatocellular liver carcinoma cells (HepG2). In a comparison between the HEK293 and HepG2, we could not find any difference in the ligand-specificities. It suggests that human coregulator proteins for the transactivation in HEK293 and HepG2 are available for corticoid receptor activation from different tissues. However, we still don't know that the cell lines from other species will give any differences in the ligand-specificity.

We also examined the sensitivity of each receptor to activation by different hormones and observed that all of the natural steroids tested, stimulated aGR- and aMR-induced luciferase activity in a dose-dependent manner (Fig. 6). The EC50s for each hormone when tested with the aGR or aMR are reported in Table 1 , as are the relative potencies and efficacies. Previously, Rupprecht et al. (1993) reported that a high concentration of aldosterone was necessary for the transactivation of human GR. We analyzed the transactivation of human GR by aldosteorne and cortisol in our assay system, and EC50s of human GR for aldosterone and cortisol was $1.956 \times 10^{-7} \mathrm{M}$ and $9.80 \times 10^{-9} \mathrm{M}$, respectively (Fig. 7A). These results suggest that alligator GR is more sensitive to aldosterone compared with human GR. Rogerson et al. (1999) reported that amino acids 
804-874 of the human MR are critical for aldosterone binding. They also showed that more limited region, 820-844 of the human MR are critical for binding of aldosterone to the MR (Rogerson et al., 2007). The alignment analyses of human MR, human GR, and alligator GR showed two amino acids residues (Lys617 and Asn620) of alligator GR coincide with the human MR, but not human GR (Fig. 7B). Further study is necessary for mechanisms of aldosterone-sensitivity of alligator GR.

\subsection{Ligand-sensitivity of vertebrate corticoid receptors}

To analyze species- and receptor-specificity, a full-length GR or the MR from various species was cotransfected with a luciferase reporter driven by MMTV-LTR. Transfected cells were treated with aldosterone, deoxycorticosterone, corticosterone, cortisol, cortisone, pregnenolone or progesterone. The chicken GR was activated by cortisone and pregnenolone, but these steroids did not stimulate human, Xenopus, and zebrafish GRs (Fig. $8 \mathrm{~A} \sim 8 \mathrm{G})$. Cortisol is the strong activator of zebrafish GR, however, zebrafish MR was activated by all of the steroids examined (Fig. $8 \mathrm{G}$ and $8 \mathrm{H}$ ). Interestingly, the ligand-specificity of human, chicken and Хеnориs GRs were similar to that of each species MRs (Fig. 8). As we used a saturating dose of ligand in this reporter gene assay, the ligand-specificity indicated the transcriptional efficacy, but not the potency (Nettles and Greene, 2005). We will examine the dose-dependency of each GR an MR for analyses of ligand-dependency in detail in the near future.

\section{Discussion}

Glucocorticoids and mineralocorticoids help regulate a variety of physiological processes, including reproduction, metabolism, salt balance, inflammation, and immunity (Barnes and Adcock, 2003). In reptiles, corticosterone increases throughout embryonic development until hatching (Jennings et al., 2000; Medler and Lance, 1998). By the time young reach the juvenile stage, turtles secrete significantly higher baseline and stress-induced corticosterone in response to capture and restraint stress than non-breeding adults (Jessop et al., 2004; Jessop and Hamann, 2005). However, although a number of papers have reported stress-induced changes in plasma concentrations of corticosterone, the characterization of reptilian corticosteroid receptors is incomplete. Mehi et al. (1987) reported a protein with corticosteroid binding affinity in the gut of the turtle (Chrysemys picta) and a partial DNA fragment for GR was isolated from the American alligator, A. mississippiensis (GenBank accession number AF525750) previously by our group. Recently, predicted full-length GR and partial-length MR cDNA sequences of the lizard, the green anole (A. carolinensis) were registered in GenBank (GR for XM_003217373 and MR for XM_003221723). These 
sequences were derived from a genomic sequence (NW_003338615 for GR, and NW_003338716 for MR) annotated using the gene prediction method, GNOMON (The NCBU eukaryotic gene prediction tool; http://www.ncbi.nlm.nih.gov/genome/guide/gnomon.shtml), supported by EST evidence. Although reptiles represent the basal lineage in the amniote vertebrates, relatively little is known concerning the molecular action of steroids and steroid receptor signaling in this group. A growing literature exists on sequence and evolutionary phylogeny for various vertebrate steroid receptors, however, few studies have examined reptilian receptors and fewer have examined hormone-induced transcriptional activity of these receptors with various known steroids so that cross species comparisons can be made.

The alligator corticosteroid receptors cloned and sequenced as part of this paper exhibit strong sequence similarity to corticosteroid receptor genes reported from mammals and birds. The alligator, like other amniote vertebrates, have two corticosteroid receptors, an aGR and an aMR. We observed that the DNA binding region of the GR and MR, the ' $\mathrm{C}$ ' region using Krust et al. (1986) terminology, was highly conserved, having 100\% sequence similarity with the GR and MR cloned from human, chicken and alligator. A P-box motif (CGSCKV) in the DBD was identified in the alligator GR and MR. These data suggest that the glucocorticoid response-elements in the promoters of genes from these species also are likely conserved.

Although less data are available to produce a similar comparison for the GR and MR in other vertebrate species, our data support highly conserved sequence similarities among species of amniotes in the DNA and ligand binding regions for these receptors. The aGR and aMR are closely related phylogenetically to similar receptors found in bird or mammals. Given the diverse roles of various corticosteroids among vertebrates, it was surprising not to see more variation in receptor sequence in the DNA and ligand binding regions.

We compared the amino acid residues for ligand-binding pocket of each GRs and MRs. MRs of five species (human, chicken, alligator, Xenopus, and zebrafish) had the same sets of the amino acid residues on the ligand-binding pocket, whereas two different amino acids in ligand-binding pocket between human GR and alligator GR were identified. Further, only one amino acid residue of chicken GR was not identical to zebrafish GR despite the different ligand-specificity (supplemental data Figure S1). It suggests that the amino acid residues corresponding to ligand-binding pocket would be important for the ligand-binding, but other amino acid residues might be involved in ligand-specificity of steroid receptor. It has been reported that a substitution of the amino acid residue affected the conformation change and altered ligand-specificity, although the amino acid residue was distant from the ligand-binding pocket (Arterbery et al., 2011; Ortlund et al., 2007; Rogerson 
et al., 2004). Although we don't have any information for co-regulator proteins of alligator corticoid receptors, a GR-mediated ligand-selective differential interaction with co-regulators is a major determinant of ligand-selective and promoter-specific differences in potency and efficacy for transactivation (Ronacher et al., 2009) in mammals. Thus, the analyses of the protein interaction for alligator corticoid receptors might be useful for understanding the ligand-specificity and transcriptional efficacy. Further, since the interaction between the Nand C-terminal domains is ligand-specific, MR undergoes ligand-specific conformational changes. This conformational change might affect the interaction with co-regulator proteins which would induce the ligand-specificity (Pippal et al., 2001; Huyet et al., 2012; Fuller et al., 2012).

In summary, we have cloned and sequenced the corticosteroid receptors, GR and MR, and characterized these receptors from the American alligator (A. mississippiensis). Further, we have compared the functioning of these receptors in vitro, with related receptors from other phylogenetically distinct species. This is the first report of the full-length sequences for a reptile combined with the characterization those receptors using an in vitro transcriptional activity assay. These data provide a useful approach for future studies examining the basic endocrinology of non-mammalian steroid hormone receptors. Reporter gene assays, using Gal4-fused and full-length GR gene, need to provide a further examination of an interaction of the $\mathrm{A} / \mathrm{B}$ domain and ligand-binding domain for ligand-binding and transcriptional activation. Further, our data will help provide basic molecular data useful in examining the role of GR and/or corticosteroids in gonadal development, sex-differentiation, endocrine system and reproductive biology of reptiles.

\section{Acknowledgments}

We thank colleagues in our laboratories. This work was carried out under the auspices of the National Institute for Basic Biology Cooperative Research Program (10-335, 11-322, and 12-326 to YK), a grant from the National Institute for Basic Biology (TI), and supported in part by Grants-in-Aid for Scientific Research 20570064 and 23570067 (YK), and 21510068 (YO), and 24370029 (TI) from the Ministry of Education, Culture, Sports, Science and Technology of Japan, and a UK-Japan collaboration grant (TI) from the Ministry of Environment, Japan, and grant from the Howard Hughes Professors Program and the CoEE Center for Marine Genomics (LJG). 


\section{References}

Arterbery, A.S., Fergus, D.J., Fogarty, E.A., Mayberry, J., Deitcher, D.L., Lee Kraus, W., Bass, A.H., 2011. Evolution of ligand specificity in vertebrate corticosteroid receptors. BMC Evo.l Biol. 14;11:14.

Barnes, P.J., Adcock, I.M., 2003. How do corticosteroids work in asthma? Ann. Intern. Med. 139, 359-370.

Belikov, S., Gelius, B., Almouzni, G., Wrange, O., 2000. Hormone activation induces nucleosome positioning in vivo. EMBO J. 19, 1023-1033.

Bridgham, J.T., Ortlund, E.A., Thornton, J.W., 2009. An epistatic ratchet constrains the direction of glucocorticoid receptor evolution. Nature 461, 515-519.

Couette, B., Le Ricousse, S., Fortin, D., Rafestin-Oblin, M.E., Richard-Foy, H., 1994. The establishment of the long terminal repeat of the mouse mammary tumor virus into CV-1 cells allows a functional analysis of steroid receptors. Biochim. Biophys. Acta. $1219,607-612$.

Dereeper, A., Guignon, V., Blanc, G., Audic, S., Buffet, S., Chevenet, F., Dufayard, J.F., Guindon, S., Lefort, V., Lescot, M., Claverie, J.M., Gascuel, O., 2008. Phylogeny.fr: robust phylogenetic analysis for the non-specialist. Nucleic Acids Res. 36, W465-469.

Deroo, B.J., Archer, T.K., 2001. Glucocorticoid receptor-mediated chromatin remodeling in vivo. Oncogene 20, 3039-3046.

Ferguson, M.W.J., 1985. Reproductive biology and embryology of the crocodilians. In: Gans C. Maderson P, Billete F (eds): Biology of the Reptilia, vol 14, pp329-491 (Wiley and Sons, Yew York).

Fuller, P., Yao, Y., Yang, J., Young, M.J., 2012. Mechanisms of ligand specificity of the mineralocorticoid receptor. J. Endocrinol. 213, 15-24.

Govindan, M.V., Leclerc, S., Roy, R., Rathanaswami, P., Xie, B.X., 1991. Differential regulation of mouse mammary tumor virus-bacterial chloramphenicol 
acetyltransferase chimeric gene by human mineralocorticoid hormone-receptor complexes. J. Steroid Biochem. Mol. Biol. 39, 91-103.

Huyet, J., Pinon, G.M., Fay, M.R., Rafestin-Oblin, M.E., Fagart, J., 2012. Structural determinants of ligand binding to the mineralocorticoid receptor. Mol. Cell. Endocrinol. 350, 187-195.

Jennings, D.H., Weiss, S.L. Moore, M.C., 2000. Ontogenic changes in embryonic yolk steroid content in tree lizards: transfer of hormones from the developing embryo to the york? Am. Zool. 40, 1075-1076.

Jessop, T.S., Sumner, J.M., Limpus, C.J., Whittier, J.M., 2004. Interplay between plasma hormone profiles, sex and body condition in immature hawksbill turtles (Eretmochelys imbricata) subjected to a capture stress protocol. Comp. Biochem. Physiol. A 137, 197-204.

Jessop, T.S., Hamann, M., 2005. Interplay between age class, sex and stress response in green turtle (Chelonia mydas). Aust. J. Zool. 53, 131-136.

Kay, P., Schlossmacher, G., Matthews, L., Sommer, P., Singh, D., White, A., Ray, D. 2011. Loss of glucocorticoid receptor expression by DNA methylation prevents glucocorticoid induced apoptosis in human small cell lung cancer cells. PLoS One 6(10):e24839.

Kohno, S., Katsu, Y., Urushitani, H., Ohta, Y., Iguchi, T., Guillette, L.J., 2010. Potential contributions of heat shock proteins to temperature-dependent sex determination in the American alligator. Sex. Dev. 4, 73-87.

Kohno, S., Guillette, L.J., 2012. Endocrine disruption and reptiles: Using the unique attributes of temperature-dependent sex determination to assess impacts. In: Endocrine Disrupter Risk Assessment: Testing and Prediction Methods (Matthiessen, P. ed.), J. Wiley and sons, New York

Krust, A., Green, S., Argos, P., Kumar, V., Walter, P., Bornert, J.M., Chambon, P., 1986. The chicken oestrogen receptor sequence: homology with v-erbA and the human oestrogen and glucocorticoid receptors. EMBO J. 5, 891-897. 
Majors, J., Varmus, H.E., 1983. A small region of the mouse mammary tumor virus long terminal repeat confers glucocorticoid hormone regulation on a linked heterologous gene. Proc. Natl. Acad. Sci. U.S.A. 80, 5866-5870.

Medler, K.F., Lance, V.A., 1998. Sex differences in plasma corticosterone levels in alligator (Alligator mississippiensis) embryo. J. Exp. Zool. 280, 238-244.

Mehi, A.Z., DiBattusta, J.A., Sandor, T., 1987. Characterization of steroid receptors in the gut and kidney of the frog (Rana catesbeiana) and in the gut of the turtle (Chrysemys picta). J. Steroid Biochem. 26, 627-639.

Nettles, K.W., Greene, G.L., 2005. Ligand control of coregulator recruitment to nuclear receptors. Annu. Rev. Physiol. 67, 309-333.

Norman, A.W., Litwack, G., 1997. Hormones. 2nd ed. An Diego: Academic Press

Ortlund, E.A., Bridgham, J.T., Redinbo, M.R., Thornton, J,W., 2007. Crystal structure of an ancient protein: Evolution by conformational epistasis. Science 317, 1544-1548.

Pippal, J.B., Cheung, C.M.I., Yao, Y-Z., Brennan, F.E., Fuller, P.J., 2011. Characterization of the zebrafish (Danio rerio) mineralocorticoid receptor. Mol. Cell. Endocrinol. 332, 58-66.

Rogerson, F.M., Dimopoulos, N., Sluka, P., Chu, S., Curtis, A.J., Fuller, P.J., 1999. Structural determinants of aldosterone binding selectivity in the mineralocorticoid receptor. J. Biol. Chem. 274, 36305-36311.

Rogerson, F.M., Yao, Y.Z., Smith, B.J., Fuller, P.J., 2004. Differences in the determinants of eplerenone, spironolactone and aldosterone binding to the mineralocorticoid receptor. Clin. Exp. Pharmacol. Physiol. 31, 704-709.

Rogerson, F.M., Yao, Y.Z., Elsass, R.E., Dimopoulos, N., Smith, B.J., Fuller, P.J., 2007. A critical region in the mineralocorticoid receptor for aldosterone binding and activation by cortisol: evidence for a common mechanism governing ligand binding specificity in steroid hormone receptors. Mol. Endocrinol. 21, 817-828. 
Ronacher, K., Hadley, K., Avenant, C., Stubsrud, E., Simons, S.S. Jr, Louw, A., Hapgood, J.P., 2009. Ligand-selective transactivation and transrepression via the glucocorticoid receptor: role of cofactor interaction. Mol. Cell. Endocrinol. 299, 219-231.

Rupprecht, R., Arriza, J.L., Spengler, D., Reul, J.M., Evans, R.M., Holsboer, F., Damm, K., 1993. Transactivation and synergistic properties of the mineralocorticoid receptor: relationship to the glucocorticoid receptor. Mol. Endocrinol. 7, 597-603.

Schaaf, M.J., Champagne, D., van Laanen, I.H., van Wijk, D.C., Meijer, A.H., Meijer, O.C., Spaink, H.P., Richardson, M.K., 2008. Discovery of a functional glucocorticoid receptor beta-isoform in zebrafish. Endocrinology 149, 1591-1599.

Tamura, K., Peterson, D., Peterson, N., Stecher, G., Nei, M., Kumar, S., 2011. MEGA5: molecular evolutionary genetics analysis using maximum likelihood, evolutionary distance, and maximum parsimony methods. Mol. Biol. Evol. 28, 2731-2739.

Thornton, J.W., 2001. Evolution of vertebrate steroid receptors from an ancestral estrogen receptor by ligand exploitation and serial genome expansions. Proc. Natl. Acad. Sci. U.S.A. 98, 5671-5676.

\section{Figure Legends}

Figure 1. Alligator glucocorticoid receptor (GR) and mineralocorticoid receptor (MR). (A) The deduced amino acid sequence of alligator GR. Numbers on the side represent the position of amino acid residues in sequence. (B) The deduced amino acid sequence of alligator MR. Numbers on the side represent the position of amino acid residues in sequence.

Figure 2. Domain structure of alligator GR and MR and homology with GR/MR from other species.

(A) Comparison of alligator GR with alligator MR. The functional A/B to E/F domains are schematically represented with the numbers of amino acid residues indicated. (B) Domain structure of GR in alligator, and identity with chicken, human, Xenopus, and zebrafish GRs. (C) Domain structure of MR in alligator, and identity with chicken, human, Xenopus, and zebrafish MRs. The functional A/B to E/F domains are schematically represented with the 
numbers of amino acid residues indicated. The numbers within each box indicated the percent identity of the domain compared to alligator GR or GR. GenBank accession: human GR; NM_000901, chicken GR; NM_001159345, Xenopus GR; NM_001090605, zebrafish GR; NM_001100403). Numbers (\%) shows the over-all identity. (C) Comparison of alligator MR with MRs of several species (human, chicken, Xenopus, and zebrafish; GenBank accession: human MR; NM_000176, chicken MR; NM_001037826, Xenopus MR; NM_001088062, zebrafish GR; NM_001100403).

Figure 3. Phylogeny of vertebrate GR, MR, PR and AR.

Newly cloned alligator GR and MR revealed high similarity to the sequences in the database. The small number on each branch indicates the branch support value estimated in PhyML program. The scale bar indicates 0.2 expected amino acid substitutions per site.

Figure 4. Tissue distribution of GR and MR mRNA in American alligator.

Total RNA was prepared from gonad (G), kidney (K), liver (L), pancreas (P), spleen (S), and thyroid (T) from both female (A) and male (B) alligator. Actin was used a positive control. (C) Expression of corticoid receptor mRNAs by RT-PCR in GAMs from alligator. The mRNA expression of alligator GR, MR and EF1 $\alpha$ (control) were detected in GAMs at embryonic stages 19 and 24.

Figure 5. Transcriptional activities of alligator GR and MR.

Transcriptional activities of alligator GR (A) or alligator MR (B) for various steroids. HEK293 cells were transiently transfected with the MMTV-luciferase vector together with an alligator GR expression vector. Cells were incubated with $10^{-6} \mathrm{M}$ of aldosterone (aldo), deoxycorticosterone (DOC), corticosterone (CORT), cortisol, cortisone, pregnenolone (preg), progesterone ( $\mathrm{P} 4)$, androstenedione (andro), 5 $\alpha$-dihydrotestosterone (DHT), 17 $\beta$-estradiol (E2), and diethylstilbestrol (DES). Data are expressed as a ratio of steroid:vehicle (dimethylsufoxide, DMSO). Each bar represents the mean of the triplicate determinations, and vertical bars present the mean \pm SEM.

Figure 6. Transcriptional activities of alligator GR and MR.

(A) Transcriptional activities of alligator GR for various steroids. HEK293 cells were transiently transfected with the MMTV-containing vector together with an alligator GR expression vector. Cells were incubated with increasing concentrations of corticosterone (CORT), cortisol, cortisone, aldosterone (Aldo), deoxycorticosterone (DOC), and progesterone $(\mathrm{P} 4)\left(10^{-13} \mathrm{M}-10^{-6} \mathrm{M}\right)$. (B) Transcriptional activities of alligator $\mathrm{MR}$ for 
various steroids. HEK293 cells were transiently transfected with the MMTV-containing vector together with an alligator MR expression vector. Cells were incubated with increasing concentrations of aldosterone (Aldo), deoxycorticosterone (DOC), corticosterone (CORT), cortisol, and progesterone (P4) $\left(10^{-13} \mathrm{M}-10^{-6} \mathrm{M}\right)$. Data are expressed as a ratio of steroid:vehicle (DMSO). Each column represents the mean of triplicate determinations, and vertical bars represent the mean \pm SEM.

Figure 7. Transcriptional activities of human GR. (A) Transcriptional activities of human GR for cortisol and aldosterone. HEK293 cells were transiently transfected with the MMTV-containing vector together with a human GR expression vector. Cells were incubated with increasing concentrations of cortisol, cortisone and aldosterone $\left(10^{-12} \mathrm{M}-10^{-6}\right.$ M). Data are expressed as a ratio of steroid:vehicle (DMSO). Each column represents the mean of triplicate determinations, and vertical bars represent the mean \pm SEM. (B) Amino acid alignment of alligator GR (617-641), human GR (614-638), and human MR (820-844). The numbers on the right refer to the amino acid position. Astarisks indicate residues conserved in all receptors. \# indicates the same residues of alligator GR and human MR, but not human GR.

Figure 8. Transcriptional activities of various vertebrate GRs and MRs.

HEK293 cells were transiently transfected with the MMTV-containing vector together with a full-length human GR (A), human MR (B), chicken GR (C), chicken MR (D), Xenopus GR (E), Xenopus MR (F), zebrafish GR (G), zebrafish MR (H). Cells were incubated with $10^{-6} \mathrm{M}$ of aldosterone (Aldo), deoxycorticosteorne (DOC), corticosteorne (CORT), cortisol, cortisone, pregnenolone (Preg), progesteorne (P4), or vehicle (DMSO). Each bar represents the mean of the triplicate determinations, and vertical bars present the mean \pm SEM. 
Table 1. Gene transcriptional activities of steroids mediated by alligator GR and M

\begin{tabular}{|c|c|c|c|c|}
\hline & EC50 (M) & $95 \%$ CI (M) & $\mathrm{RP}(\%)$ & RE (\%) \\
\hline \multicolumn{5}{|l|}{ GR } \\
\hline Cortisol & $2.944 \times 10^{-10}$ & $1.359 \times 10^{-10}$ to $6.380 \times 10^{-10}$ & 527 & 93 \\
\hline Corticosterone & $1.551 \times 10^{-9}$ & $7.314 \times 10^{-10}$ to $3.288 \times 10^{-9}$ & 100 & 100 \\
\hline Cortisone & $5.789 \times 10^{-8}$ & $3.523 \times 10-8$ to $9.512 \times 10^{-8}$ & 3 & 84 \\
\hline Aldosterone & $2.856 \times 10^{-9}$ & $1.527 \times 10-9$ to $5.343 \times 10^{-9}$ & 54 & 89 \\
\hline Deoxycorticosterone & $2.753 \times 10^{-9}$ & $1.425 \times 10-9$ to $5.320 \times 10^{-9}$ & 56 & 95 \\
\hline Progesterone & $5.065 \times 10^{-9}$ & $1.686 \times 10-9$ to $1.522 \times 10^{-8}$ & 31 & 73 \\
\hline \multicolumn{5}{|l|}{ MR } \\
\hline Cortisol & $2.223 \times 10^{-9}$ & $1.011 \times 10-9$ to $4.886 \times 10^{-9}$ & 13 & 129 \\
\hline Corticosterone & $2.777 \times 10^{-10}$ & $1.159 \times 10^{-10}$ to $6.652 \times 10^{-10}$ & 100 & 100 \\
\hline Aldosterone & $3.265 \times 10^{-10}$ & $1.342 \times 10^{-10}$ to $7.946 \times 10^{-10}$ & 85 & 126 \\
\hline Deoxycorticosterone & $2.579 \times 10^{-10}$ & $1.155 \times 10^{-10}$ to $5.758 \times 10^{-10}$ & 108 & 77 \\
\hline
\end{tabular}

Shown are 95\% confidence intervals (CI) of EC50. Relative potency (RP) = (EC50 corticosterone/EC50 steroid X) x 100. Relative efficacy $(\mathrm{RE})=$ maximum response \% of corticosterone found at any doses. 


\section{A: alligator $\mathrm{GR}$}

1: MDPKESLNSSEREEAGKIVRFNDKGGIVMDFHPTFRGGATVKASA 46: STSPLPASTSPLPASSQSDSKQQPVLGDFSKGLVSNVPQPDLSKA 91: VSLSMGLYMGETDSKVMGNDIGFPQQGQIGISSGETDFRLLEESI 136: ASLNKSSGLAEGTKGTVSSGLSLKQDFPVMTNCNVPLEPGTLMQG 181: QIGSSGGNMKLFSEDQSTLDILQDLELPPIS PGKE PNGS PWRLDP 226: LLDEGGLLSPLAADEAFLHEGNSGEDCKPLILPDTKPKINERGDL 271: LSSPPVQMPQVKTEKEDFIELCTPGIKQEKTGPVYCQANFPGSSV 316: LGTKVSAISVHGVSTSGGQIYHYDLNTASHSQQQDQKPVFNVIPS 361: LTAGTENWNRCQGSGDDPLSPMGNLNFSGRSSFSNGYSS PGMRSD 406: VSSSPSTTSATTGPPPKLCLVCSDEASGCHYGVLTCGSCKVFFKR 451: AVEGQHNYLCAGRNDCI IDKIRRKNCPACRYRKCLQAGMNLEARK 496: TKKKIKGIQQSNVSSVRDTPESPGNKS IVPASLPQLTPTLVSLLE 541: VIEPEVLYSGYDSTLPDSSWRILSTLNMLGGRQVVAAVKWAKAIP 586: GFRNLHLDDQMTLLQYSWMFLMSFALGWRSYKQSNGNLLCFAPDL 631: I INEQRMSLPCMYEQCKNMLMVAGELSRLQVSYEEYLCMKTLLLL 676: STIPKEGLKSQALFEEIRMTYIKELGKAIVKREGNSSQNWQRFYQ 721: LTKLLDSMHEVVENLLNFCFQTFLDKSMS IEFPEMLAEI ISNQIP 766: KYSNGNIKKLLFHQK* 780

\section{B: alligator MR}

1: METKGYHSYPEGLDMEKRWSQVSQSAEYSSLGAGEQTDESNYMEI 46: VNVSCITGAFPNSNAQGNGKEKPELLACLQQDSNQPGILTSDIKT 91: ESDSKELSATVAESMGLYMDS IRDADYTYDQQNQGSPGKIYQNVE 136: QLVKFYKENGHCSS PLNNATRPLRSLMSDSGSSVNGGVMHTIIKS 181: PIMCQEKSPSGCSPQNMTSSVCSPAGINSVSSTTTNFGNFVVNSP 226: INQGTPLSCSPNIENRGSMLHSPAHASNVGSPLSSPISSMKSPIS 271: SPPSHCSVKSPVSS PNNITMRSSVSSPANMNSRSSIASPSNANNR 316: STLSSPAVSTVGSSICSPVNNSLGFSAAGTPGGLSRGQDTVPSPE 361: TKDKGAQEITFPKMEEIENAISNNGQMNLAQFIKPEPDGTFGSAC 406: IGENSKINSDSPFSVPVKQESAKHSCSGASFKRNPTINPFPFSDG 451: SYFSFMDDKDYYTLSGILGPPVSSFDGSCEGSGFPNPGLPVGIKQ 496: EPDDGSYYQENRLPSSAIVGVNSGGQSFHYRIGAQGTISLSRPVA 541: REQTFQHLSAFPPVSTLVETWKSHPDLSSRRNDGYPVLEYIPENV 586: SSSSLRSVSTGSSRPSKVCLVCGDEASGCHYGVVTCGSCKVFFKR 631: AVEGQHNYLCAGRNDCI IDKIRRKNCPACRLQKCLQAGMNLGARK 676: SKKLGKLKGMHEEQSQPQPQQQQQQPPPQSPEEGTTYIAPVTEPS 721: VNTALVPHVSISPALTPAPVKILESIEPEIVYAGYDSSKPDTAEY 766: LLSTLNRLAGKQMIQVVKWAKILPGFRNLPLEDQITLIQYSWMCL 811: SSFALSWRSYKHTNSQFLYFAPDLIFDEERMRHSAMFELCQGMHQ 856: ISLQFVRLQLSFEEYTIMKVLLLLSTVPRDGLKSQAAFEEMRANY 901: IKELKKMVTKCPSNSGQSWQRFYQLTKLLDSMHDLVTDLLEFCFY 946: TFRESQALKVEFPAMLVEI ISDQLPKVESGNAKPLYFHRK* 985 
A

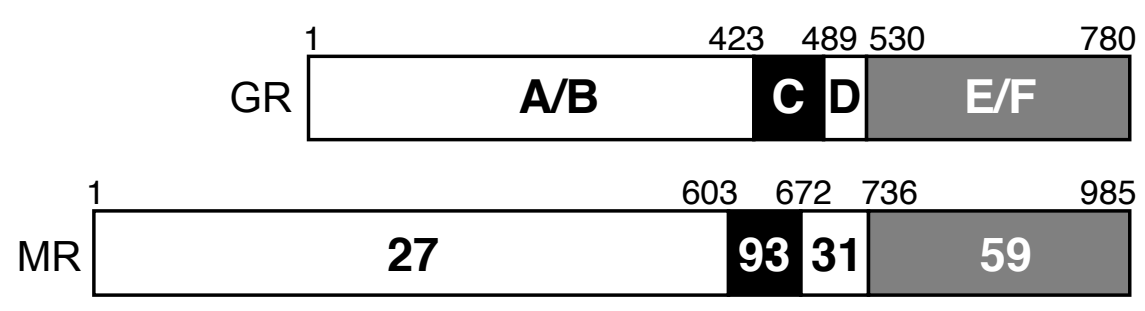

B: GR

\begin{tabular}{|c|c|c|c|}
\hline \multirow[b]{2}{*}{ Alligator } & \multicolumn{3}{|c|}{$423 \quad 491 \quad 531$} \\
\hline & $A / B$ & C $\mathrm{D}$ & $E(F)$ \\
\hline \multirow[b]{2}{*}{ Chicken } & & 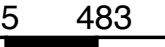 & \\
\hline & 76 & 10070 & 97 \\
\hline \multirow[b]{2}{*}{ Human } & & 88 & \\
\hline & 67 & 10070 & 90 \\
\hline \multirow{3}{*}{ Xenopus } & & 487 & \\
\hline & 54 & 10060 & 83 \\
\hline & & 454 & \\
\hline Zebrafish & 34 & 9741 & 73 \\
\hline
\end{tabular}

\section{C: MR}

\begin{tabular}{|c|c|c|c|}
\hline \multirow[b]{2}{*}{ Alligator } & \multicolumn{3}{|c|}{$\begin{array}{lll}603 & 671 & 735 \\
\end{array}$} \\
\hline & A/B & C D & $E(F)$ \\
\hline \multirow[b]{2}{*}{ Chicken } & & 671 & \\
\hline & 87 & 10086 & 98 \\
\hline \multirow{3}{*}{ Human } & & 670 & \\
\hline & 78 & 10078 & 92 \\
\hline & & $99 \quad 667$ & \\
\hline \multirow[t]{2}{*}{ Xenopus } & 60 & 9958 & 85 \\
\hline & & 668 & \\
\hline Zebrafish & 44 & 9740 & 74 \\
\hline
\end{tabular}

Figure 2 


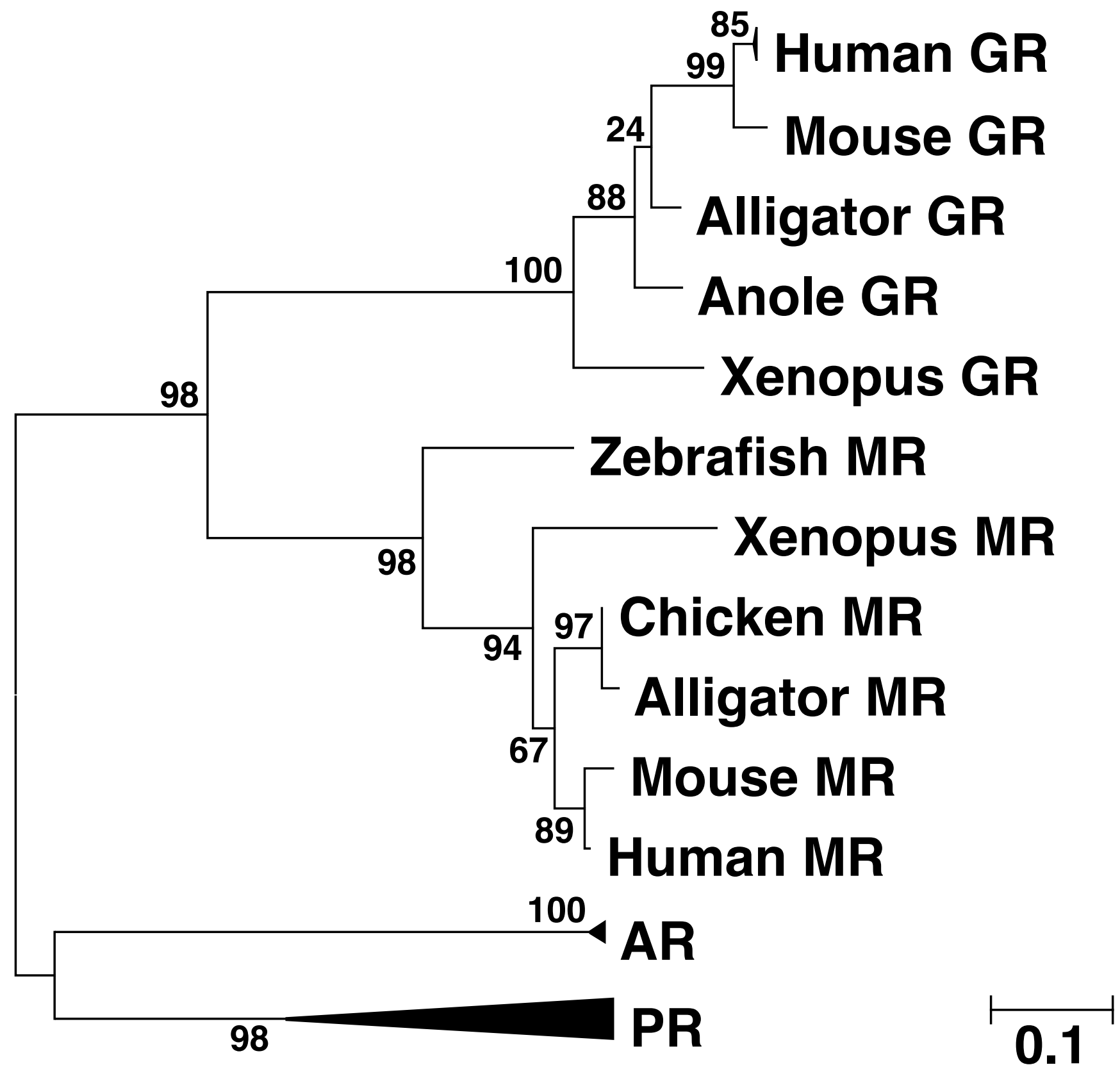

Figure 3 
A

female

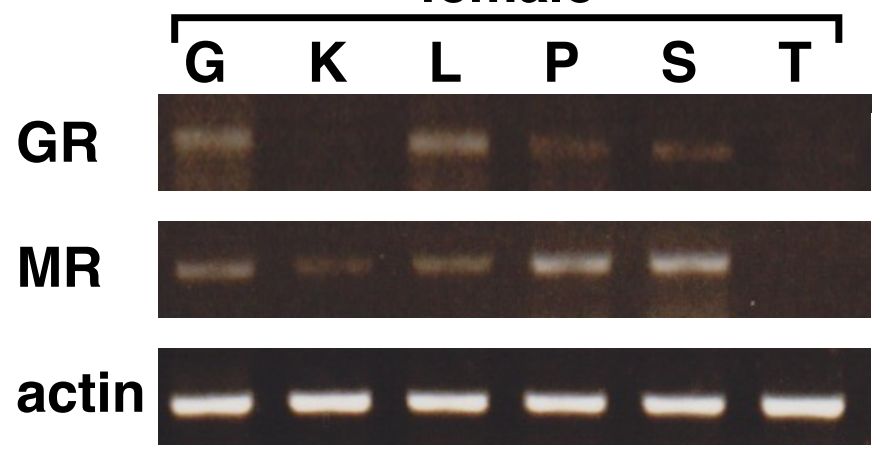

B male

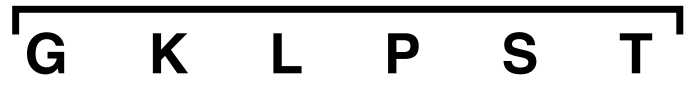

GR

MR

actin

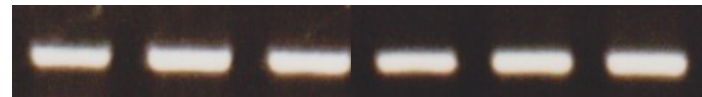

C stage 19 stage 24

GR

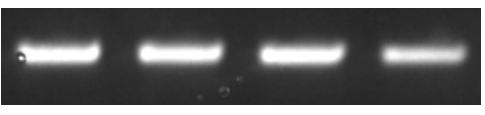

MR

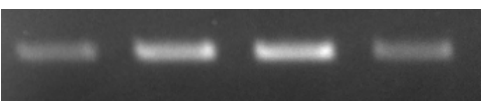

$E F 1 \alpha$

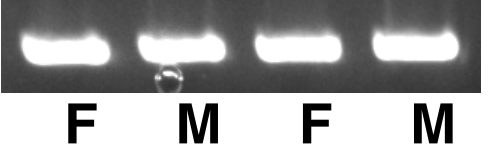

Figure 4 


\section{A: alligator GR}

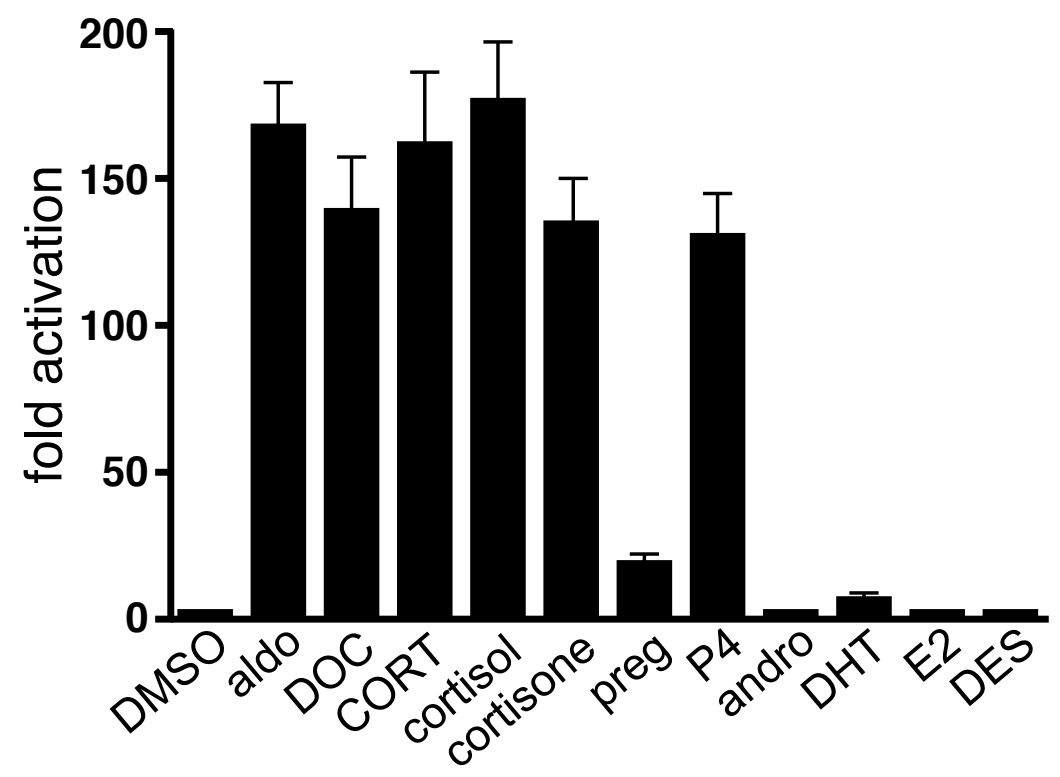

B: alligator MR

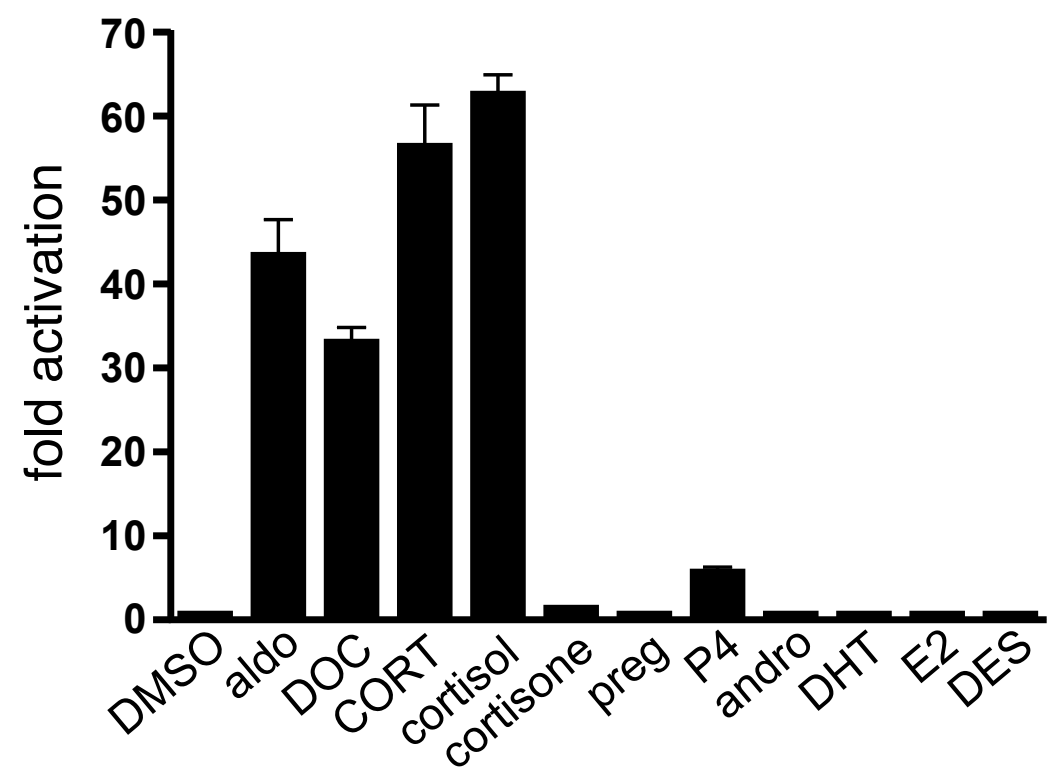

Figure 5 
A: alligator GR

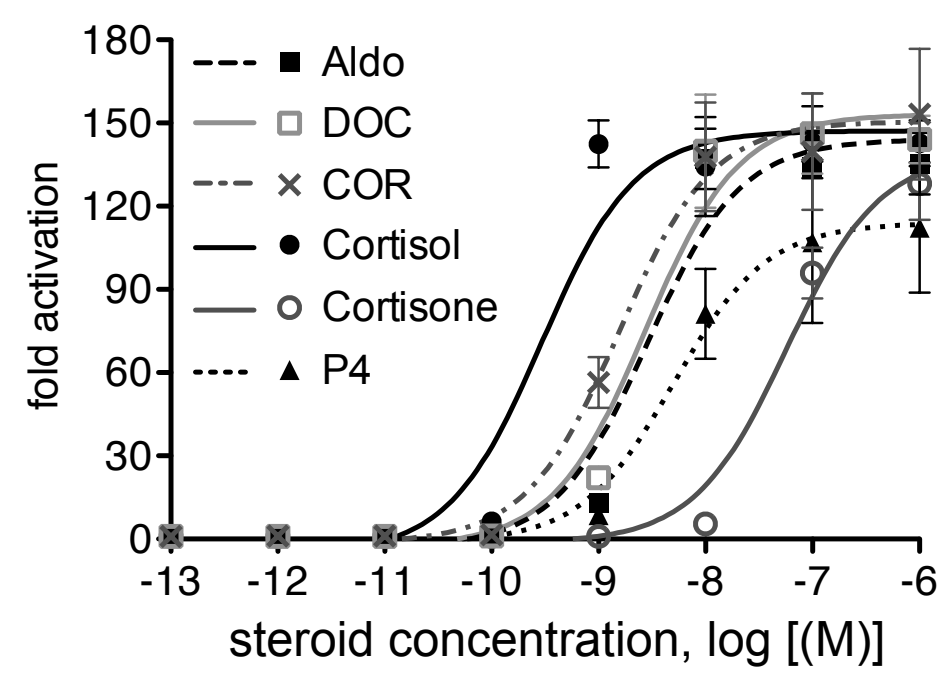

B: alligator MR

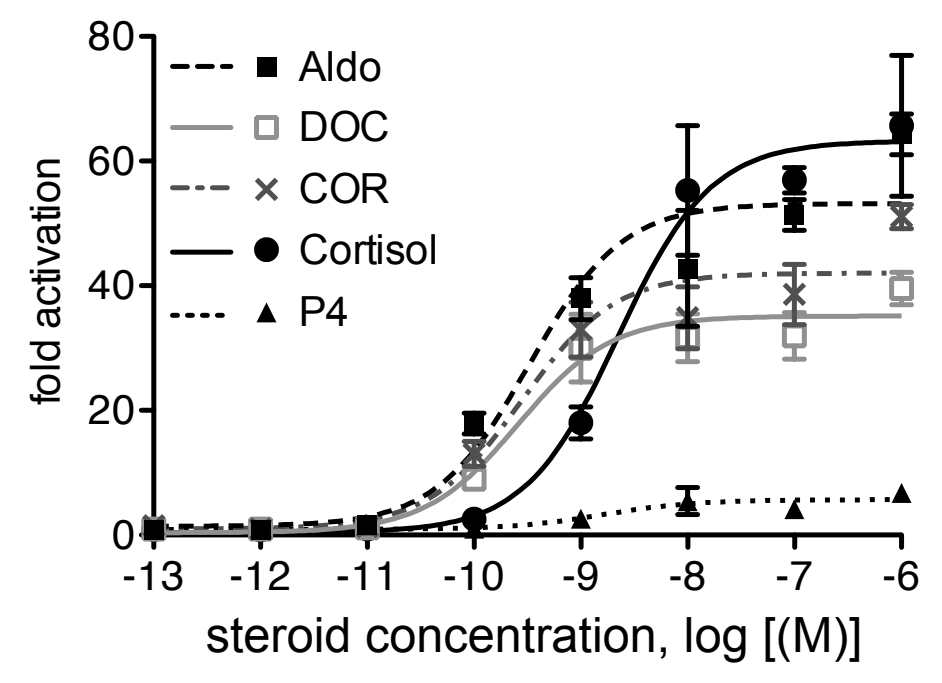

Figure 6 


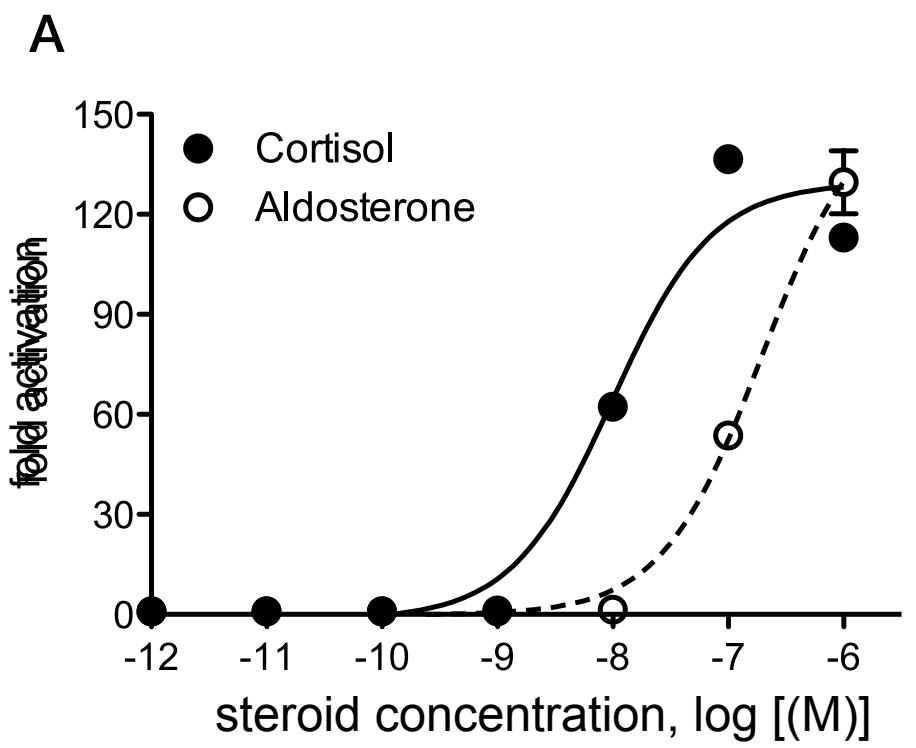

B

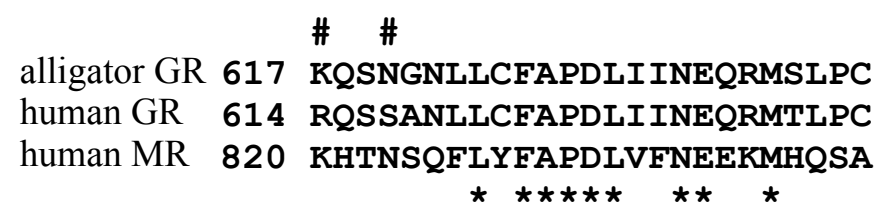

Figure 7 

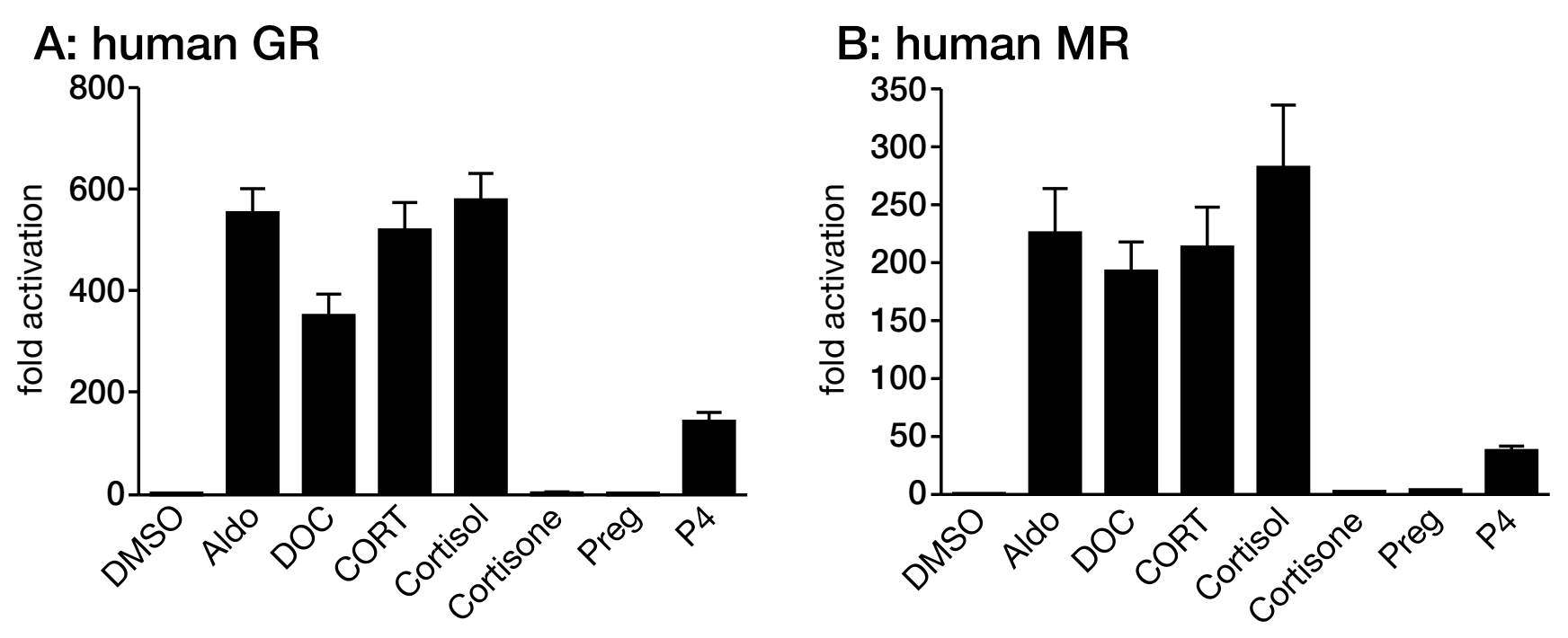

\section{C: chicken GR}

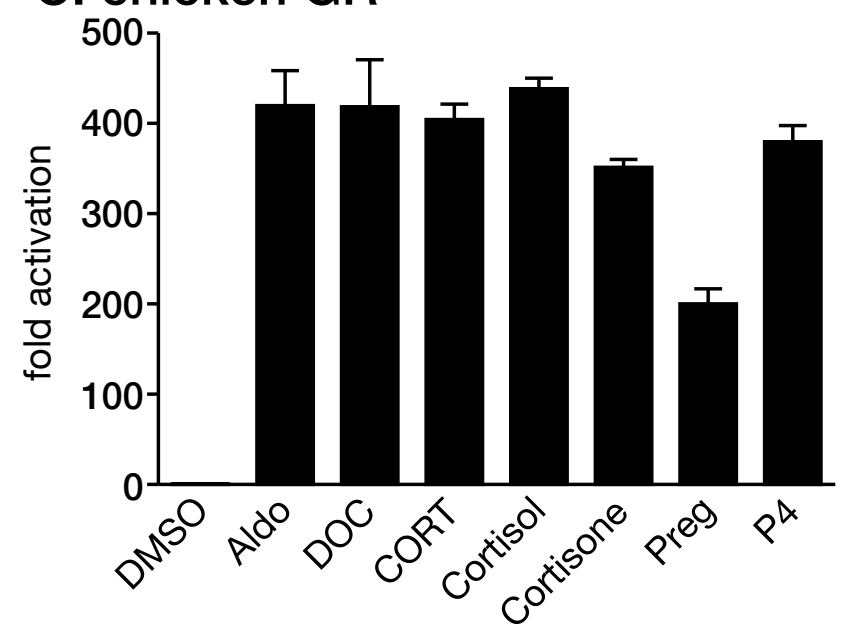

D: chicken MR

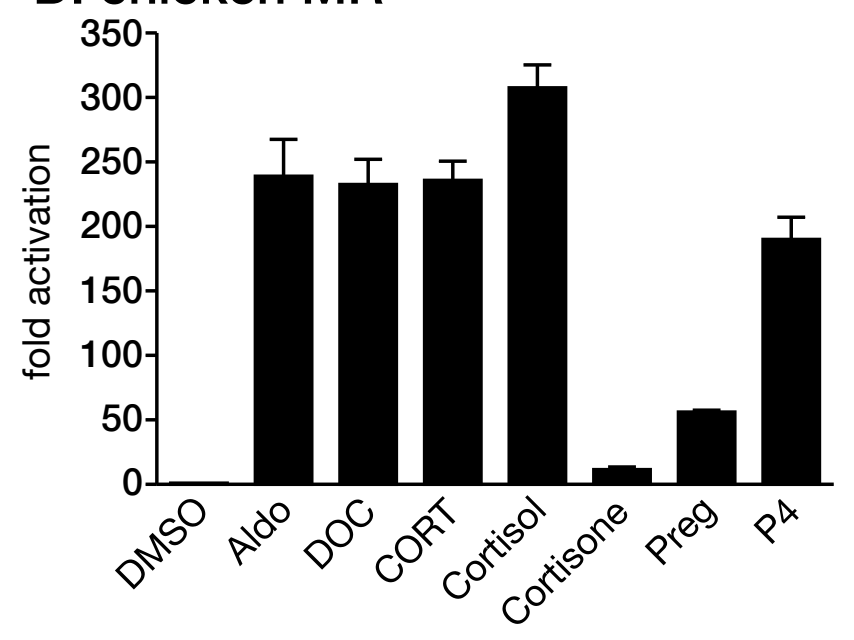

E: Xenopus GR

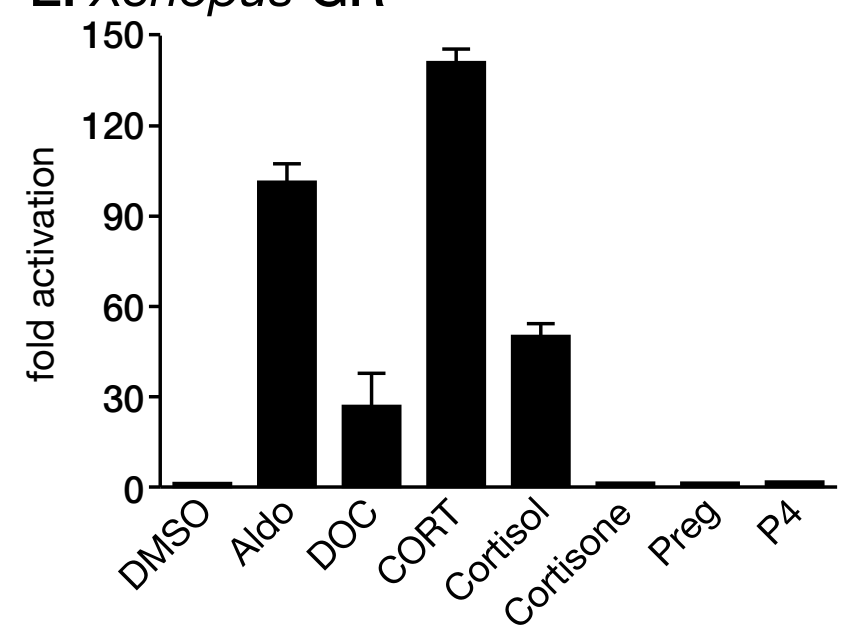

F: Xenopus MR

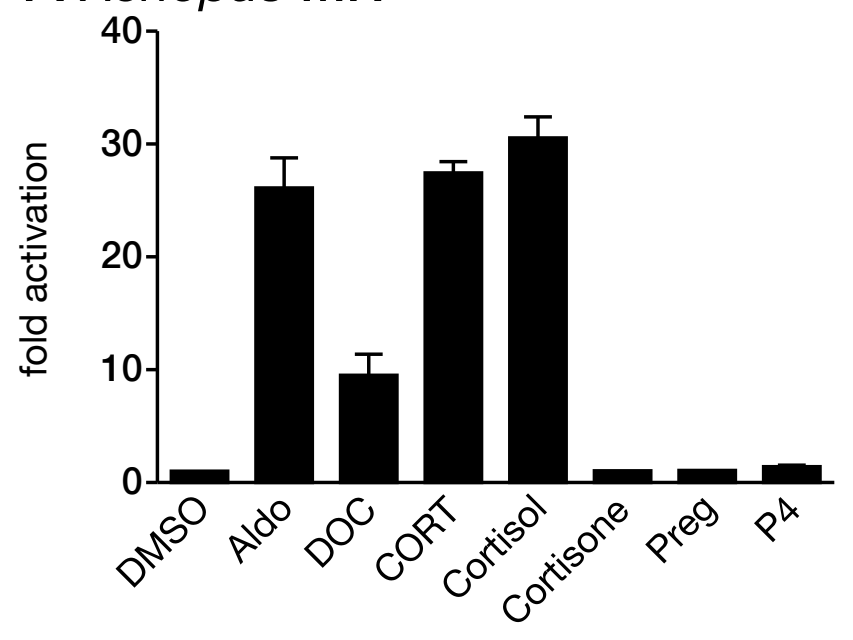

G: zebrafish GR

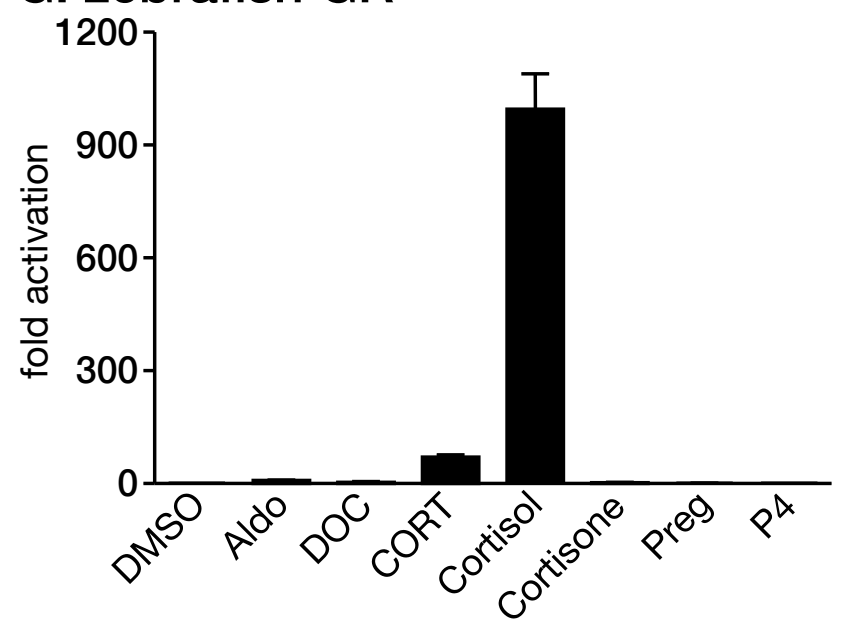

H: zebrafish MR

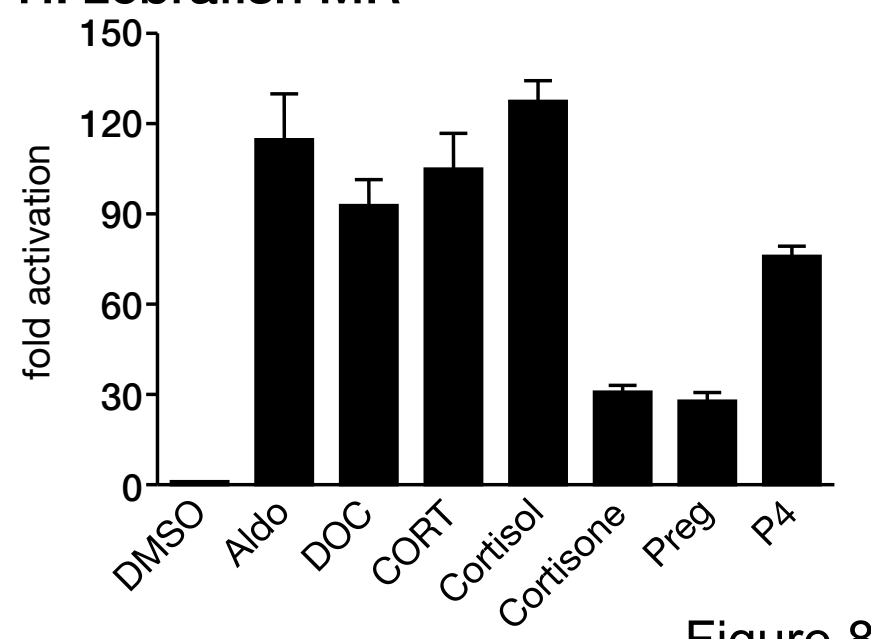

Figure 8 